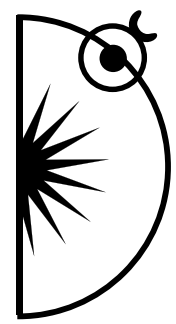

Sławomira Sadowska

Uniwersytet Gdański, e-mail: s.sadowska@ug.edu.pl

\title{
Kształcenie integracyjne dzieci \\ z niepełnosprawnością intelektualną - krytyczny bilans pierwszych strukturalnych zmian w systemie edukacji
}

http://dx.doi.org/10.12775/PBE.2016.076

\section{Integrated Education of Children with Intellectual Disability - Critical Review of the First Structural Changes in the Educational System}

\begin{abstract}
The analysis refers to the idea of integrated education with its systemic solutions on the one hand, and on the other to particular actions, both open and hidden patterns of thinking and behaviours of teachers and other people connected with the introduction of these changes. Pedagogical reflection is set in certain values. On the basis of the analysis of reforms of the educational system there are mechanisms, which play a role in fulfilling the idea of justice and equality at school. As far as the students with intellectual disability are concerned, there are numerous obstructions (environmental, these concerning the strategies of learning and teaching, behavioural, organizational and administrational) presented. These obstructions make it impossible for children with intellectual disability to take full part in educational process. On this basis key issues concerning the discursive sensitivity and teaching hermeneutical reflection have been drawn.
\end{abstract}

Keywords: school practice, integrated education, intellectual disability, culture at school, values 


\section{Wprowadzenie}

Analiza zjawisk zachodzących w przestrzeni edukacyjnej nie należy do zadań łatwych, zwłaszcza gdy dotyczy tak złożonej kwestii jak wspólne kształcenie uczniów sprawnych i z niepełnosprawnością intelektualną. Wymaga szerokiego umocowania refleksji pedagogicznej w polu wartości, jak i realiów rzeczywistości, w obrębie której człowiek powinien być odpowiedzialny. Przypomnę, że od działających w instytucjach edukacyjnych podmiotów (podobnie jak od innych instytucji publicznych) oczekujemy działań nastawionych na realizację wartości. Kluczowe to: sprawiedliwość, równość, bezpieczeństwo, solidarność, dobro wspólne, wolność zewnętrzna (pozytywna i negatywna) (T. Buksiński, 2014). Kształt rozwiązań edukacyjnych i polityki państwa w sferze edukacji określają dziś nie tyle argumenty oparte o prawo do akceptacji i wspólnej nauki, co argumenty na rzecz sprawiedliwości społecznej i równości. Spadkobiercą integracji jest dziś włączanie (inkluzja), a kluczem do budowania nowego modelu edukacji, który sprzyjać będzie urzeczywistnianiu nowego ładu społecznego, są właśnie wartości - równość i sprawiedliwość.

Prowadzone rozważania pozwalają przyjrzeć się bliżej jawnym i ukrytym mechanizmom, które odgrywają rolę w urzeczywistnianiu wartości w świecie szkoły i w świecie życia. W sposób oczywisty analizy odnoszą się do pola idei, jak i rozwiązań systemowych, konkretnych praktyk szkolnych, świadomości podmiotów edukacyjnych, doświadczeń uczniów i ich satysfakcji ze szkoły. Przestrzeń analiz ukierunkowuje znana prawda, że to, jak sprawy się mają, nie oznacza, że tak właśnie powinny się mieć. Twórca współczesnej teorii sprawiedliwości - John Rawls stwierdza: „Naturalna dystrybucja nie jest sprawiedliwa ani niesprawiedliwa; nie jest też niesprawiedliwe, że ludzie rodzą się w określonych społecznych pozycjach. Są to po prostu fakty naturalne. Sprawiedliwe czy niesprawiedliwe jest to, w jaki sposób instytucje z tymi faktami sobie radzą" (J. Rawls, 1994, s. 147). Michael J. Sandel (2013) podnosi, że dla J. Rawlsa kluczem do sprawiedliwości jest bezstronność, którą pojmował jako postrzeganie wszystkich osób za różne i odrębne, wszystkich kultur świata i uznanych w nich zasad etycznych za niepowtarzalne. Jest to możliwe do osiągnięcia, jeśli człowiek będzie stymulowany w procesie kształcenia do takiej formy myślenia oraz takiej formy odczuwania, która pozwoli złączyć razem w jeden system wszystkie indywidualne punkty widzenia i dojść wspólnie do regulatywnych zasad, które mogą zostać uznane przez każdego, kto żyje zgodnie z nimi i to uznane $\mathrm{z}$ jego własnego punktu widzenia. 


\section{Reformy szkolne - gra na narzuconym terenie?}

Wprowadzenie możliwości wspólnej nauki uczniów pełnosprawnych i z niepełnosprawnością zaliczyć można do pobocznych odsłon reformy oświatowej w Polsce, podjętej po zmianie politycznej w 1989 r. Reformy inicjowało wejście w życie w 1991 r. ustawy o systemie oświaty (Dz.U. 1991 Nr 95, poz. 425). $\mathrm{Na}$ mocy ustawy zapewniono „możliwość pobierania nauki we wszystkich typach szkół przez dzieci i młodzież niepełnosprawną oraz niedostosowaną społecznie, zgodnie z indywidualnymi potrzebami rozwojowymi i edukacyjnymi oraz predyspozycjami” (art. 1, punkt 5). Wdrażanie integracji w polskim systemie edukacji przebiegało jednak bez systemowego podejścia. Działania nakierowane na wprowadzanie zmian, wyznaczone przebudową systemu społeczno-gospodarczego państwa, oddolnymi ruchami nauczycieli, były wzmacniane oczekiwaniami rodziców dzieci niepełnosprawnych, którzy domagali się dla swoich dzieci miejsca w systemie edukacji, oczekiwali takiej organizacji kształcenia, by uwzględniane były specjalne potrzeby edukacyjne niepełnosprawnych uczniów. To z inicjatywy rodziców lub przy bardzo dużym ich udziale powstały pierwsze przedszkola i szkoły integracyjne. Rzeczywistość nie odpowiadała edukacyjnej retoryce. Reformatorskie działania odwoływały się do, jak to określił Stanisław Kowalik (2001, s. 38-40), ,ideologii dystrybucji szczęścia”, prowadząc do rozbudzenia nieuzasadnionych oczekiwań u rodziców dzieci upośledzonych umysłowo. Silna pozytywna waloryzacja nowych rozwiązań, zwłaszcza w pierwszych latach wprowadzania integracji, odegrała znaczącą rolę w narastającej negatywnej społecznej ocenie szkół specjalnych, w umniejszeniu roli tych placówek.

Niepokojącym aspektem polskich realiów urzeczywistniania idei uczenia się niepełnosprawnych z pełnosprawnymi była coraz większa liczba dzieci z niepełnosprawnością intelektualną lekkiego stopnia pobierających naukę w szkołach ogólnodostępnych w nauczaniu tokiem zindywidualizowanym. Iwona Chrzanowska (2002), analizując realność przełomu wieków, wskazywała, że nauczanie w szkołach ogólnodostępnych przebiega bez stosownych zmian kadrowych w szkołach oraz przy braku wyraźnego wzrostu współpracy tych szkół ze specjalistami, którzy mieliby wspomagać proces edukacji tych dzieci. Przypadek ten Amadeusz Krause zaliczył do kategorii „pozory edukacji inkluzyjnej”, wskazując, że „kształcenie w tej formie, według programu dostosowanego do niepełnosprawnego ucznia, znosi rygory ustawodawcze oddziału integracyjnego i umożliwia jego nauczanie w klasie masowej bez dodatkowych zajęć uzupełniających i zatrudniania nauczyciela wspomagającego" (A. Krau- 
se 2004, s. 235). W wyniku zabiegu uczenia się dzieci z niepełnosprawnością intelektualną z pełnosprawnymi w warunkach szkoły ogólnodostępnej, jak wykazała w badaniach I. Chrzanowska (2002), dzieci z niepełnosprawnością intelektualną przejawiają najczęściej wysoki stopień nieprzystosowania do sytuacji szkolnej. Kluczowe przejawy to: unikanie kontaktów z rówieśnikami, nieśmiałość i osamotnienie, reagowanie nerwowością na sytuacje zadaniowe, roztargnienie, brak koncentracji i wytrwałości w działaniu.

Postępowanie nauczycieli/szkół niejednokrotnie można odczytać jako taktyki uosabiające obronę własnego pola interesu. „Taktyka to wyrachowane działanie, zdeterminowane brakiem właściwego umiejscowienia (locus). [...] Tak więc trzeba tu grać na narzuconym terenie, urządzonym według praw obcej siły" (P. McLaren 1994, s. 492). Niejednokrotnie jest tak, że te same warunki obiektywne raz służą za argument za integracją, innym razem - przeciw. W obliczu niżu demograficznego nauczyciele zainteresowani są pozostaniem dziecka z niepełnosprawnością w szkole. Sprzyja temu sposób rozdzielania subwencji oświatowej. Z drugiej strony, liczenie się szkół z „konsumentami oświaty" wymusza zabiegi szkół o popularność w społeczności lokalnej. Oceny dzieci o specjalnych potrzebach edukacyjnych mogą wpłynąć na obniżenie średniej ocen podawanej do wiadomości publicznej i - co za tym idzie - na mniejszą popularność danej szkoły w oczach rodziców i społeczności lokalnej. Może/musi uruchamiać to zjawisko unikania rozwiązań integracyjnych, prowadzić do selektywnego nastawienia do dzieci w toku edukacji (por. U. Eckert, 1999; P. Mittler, 2000). Podchodzenie z dystansem do nowych rozwiązań można powiązać $\mathrm{z}$ faktem, że nauczyciele szkół masowych starają się uniknąć winy i upokorzenia związanego $\mathrm{z}$ niesprostaniem wymogom kompetencji i skuteczności w wypełnianiu nowego edukacyjnego zadania. Innym razem, nacisk tak zwanej „mentalności pokoju nauczycielskiego” sprawia, że nauczyciele otwarci na integrację ulegają głosom, żeby szybko zapomnieli o tych „mądrościach”. Nauczyciele szkół specjalnych nierzadko (aczkolwiek najczęściej w ścianach pokoju nauczycielskiego) argumentują, że integracja stanowi zagrożenie ich stabilności zawodowej (por. S. Sadowska, 2005, s. 66-73).

Początkowy okres wdrażania niesegregacyjnych rozwiązań w kształceniu można określić jako burzliwy. Nauczyciele ścierali się z administracją, tradycjonaliści ze zwolennikami nowego, rodzice z pracownikami szkół. Nowe sposoby działania $w$ zakresie integracji stały się środkiem do rozgrywania starych i do prowadzenia nowych bitew, mających niewiele wspólnego z włączeniem upośledzonych w główny nurt życia. Rozdzielenie procedur administracyjnych, 
organizacyjnych, szkoleniowych między szkołą powszechną a specjalną (masowe szkoły podstawowe i gimnazja podlegają pod gminę, a szkoły podstawowe specjalne i gimnazja specjalne pod powiat) nie sprzyja kształtowaniu poczucia współodpowiedzialności za edukację wszystkich dzieci. Zauważę, że pod koniec lat 90. system szkolny owładnęły kluczowe wydarzenia reformatorskie, z których najważniejsze to: zmiana struktury systemu edukacji oraz wprowadzenie nowego ustroju szkolnego, reforma programowa, stworzenie niezależnego systemu oceniania i egzaminowania, zmiany w sposobach administrowania i nadzorowania, określenie nowych zasad finansowania szkół, wynagradzania oraz ścieżek awansów kadry dydaktycznej. W ciąg tych reform w sposób oczywisty zostało wprzęgnięte kształcenie uczniów z niepełnosprawnością. Pochodną zastosowanych mechanizmów kształtowania systemu edukacji w całym okresie reform (który odnieść można do różnych ekip politycznych i sprawowania urzędu MEN przez 18 ministrów) jest utrata poczucia sensu zmian i malejący entuzjazm dla nich wśród nauczycieli.

Warto zauważyć, że dla wielu podmiotów edukacyjnych okres poprzedzający działania wymuszone tzw. reformą strukturalną i programową był czasem nadziei na możliwość realizowania wymyślonego w czasach konspiracji projektu - wolnej, demokratycznej szkoły, szkoły bez ideologicznych nacisków, skoncentrowanej na kreowaniu najkorzystniejszych warunków dla wszechstronnego rozwoju ucznia (por. Z. Puchalski, 2014, Z.A. Kłakówna, 2010). Nadzieje nauczycieli dotyczyły także usunięcia tych elementów systemu, które ograniczały ich poczucie wolności. Wskazywali zwłaszcza na: niekompetentny sposób zarządzania oświatą, nadmierną biurokratyzację czynności pedagogicznych, złą organizację pracy nauczyciela w szkole, instrumentalne ocenianie nauczyciela, zbyt sztywne ramy programowe i za małą ilość czasu na ich realizację, zbyt dużą liczbę uczniów w klasie (B. Śliwerski, 1998, s. 113). Kolejne lata, mówiąc słowami Zofii Agnieszki Kłakówny (2010, s. 15), skutkowały raczej przywracaniem bezwzględnej podmiotowości przede wszystkim kolejnym ministrom edukacji i odzyskiwaniem szkoły jako pola politycznych strategii, a nauczycielski entuzjazm i wola wprowadzenia istotnych zmian w szkole, charakterystyczne dla początkowego okresu transformacji ustrojowej, zostały wygaszone i w zasadzie zmarnowane.

Czas ciągłych reform dobrze ilustrują zmieniające się rozporządzenia dotyczące właściwie wszystkich obszarów polskiej szkoły. Pole kształcenia specjalnego, doregulowywane zmieniającymi się rozporządzeniami, było obszarem nie tylko ciągłych zmian, ale i urzędniczych pozorów i intuicji. Wejście w życie reformy programowej czy stworzenie niezależnego systemu oceniania i egza- 
minowania odsłania znaczące fakty. Lista ministerialna programów kształcenia uczniów z niepełnosprawnością w okresie wdrażania reformy programowej nie była tak bogata jak dla uczniów pełnosprawnych i sytuacja nie poprawiała się w kolejnych latach. Zamieszczony na stronach Ministerstwa wykaz programów dla uczniów z niepełnosprawnością intelektualną w stopniu lekkim wskazywał we wrześniu 2005 r., że dla etapu pierwszego (kształcenie zintegrowane) zatwierdzono 4 programy nauczania. Zauważyć należy, że nauczyciele klas I-III szkoły podstawowej na początku reformy mogli wybierać spośród 54 programów. Do nauczania matematyki uczniów z niepełnosprawnością intelektualną w stopniu lekkim na drugim etapie edukacyjnym (klasy IV-VI szkoły podstawowej) zatwierdzone były tylko 3 programy, a na etapie trzecim (gimnazjum) 4 programy. Odrębną sprawą była kwestia ich dostępności. Niektóre programy znane były nauczycielom tylko z tytułów i nazwisk autorów umieszczonych na liście MEN. Brak jakichkolwiek danych o możliwościach dotarcia do nich sprawiał, że skorzystanie z nich była fikcją (por. S. Sadowska, 2006a). Nauczyciel oczywiście mógł opracować własny program. Poważne problemy dotyczyły jednak dwóch kwestii: umiejętności nauczyciela konstruowania własnego programu i celu jego tworzenia. Z praktyki szkolnej wiadomo, że decyzje o napisaniu programu podejmowali nauczyciele najczęściej z innych powodów niż niezaspokojenie oczekiwań co do wartości obowiązujących programów i możliwości ich realizacji we własnej pracy. Aktywność tworzenia własnych programów wzrastała w okresie zdobywania kolejnych stopni awansu zawodowego. Oczywiście można ten fakt interpretować jako znak poszukiwań przez „refleksyjnych praktyków" sposobów zwiększenia efektywności własnej pracy, jednak bliższe prawdy wydaje się stwierdzenie, że jest to podyktowane koniecznością spełnienia wymogów awansu. Powstawały więc programy „nowe”, ale nie lepsze (por. S. Sadowska, 2006a).

Działaniom reformatorów zdaje się towarzyszyło ukryte przeświadczenie, że sprawdzanie i ocenianie umiejętności uczniów z niepełnosprawnością może być owiane tajemnicą zarówno w warstwie wymagań edukacyjnych, jak i jawności wyników. Początkowo zakres wymagań egzaminacyjnych opisany był w standardach wymagań egzaminacyjnych przygotowanych przez Centralną Komisję Egzaminacyjną oraz przyjętych przez Ministra Edukacji Narodowej. Obecnie umiejętności, które uczeń ma posiąść i treści nauczania, jakie powinien opanować na zakończenie danego etapu kształcenia, zapisane są w podstawie programowej. Jest ona wspólna dla wszystkich uczniów z wyjątkiem uczniów z niepełnosprawnością intelektualną stopnia umiarkowanego, znacznego i głębokiego. Kwestia braku zróżnicowania wymagań egzaminacyjnych dla uczniów, 
którzy zobowiązani są przystąpić do egzaminu, jest wyraźnie dyskusyjna w odniesieniu do uczniów z upośledzeniem umysłowym w stopniu lekkim. Ciekawe jest także to, że niejednokrotnie owiane są tajemnicą kryteria oceny na egzaminie zewnętrznym. Zdarzało się także, że były one odmienne w stosunku do tych, jakie zamieszczono w informatorze opracowanym przez Centralną Komisję Egzaminacyjną (por. S. Sadowska, 2013; S. Sadowska, Z. Janiszewska-Nieścioruk, 2015b). W sprawozdaniach CKE o wynikach egzaminu dla grup osób ze specjalnymi potrzebami edukacyjnymi widnieją jedynie podstawowe parametry statystyczne, które nie są opatrzone żadnym komentarzem (taki komentarz opracowywany jest dla uczniów bez dysfunkcji). Konstruowanie zadań dla uczniów z niepełnosprawnością intelektualną można w sposób wyraźny powiązać z urzędniczą intuicją. Średnie wyniki uczniów z niepełnosprawnością intelektualną w zadaniach podporządkowanych standardowi pisanie nierzadko są wyższe niż średnie wyniki uczniów bez dysfunkcji, na co wskazuje szczegółowy wgląd w domenę wyników zewnętrznych egzaminów (por. I. Chrzanowska, 2002, 2013; S. Sadowska, 2013; S. Sadowska, Z. Janiszewska-Nieścioruk, 2015b). Odnotować należy, że głosy nauczycieli uczniów z niepełnosprawnością intelektualną poddawały krytyce także zbyt duże wymagania, jakie zostały postawione tej grupie uczniów na poziomie rozszerzonym na pierwszym egzaminie z języka obcego. Brak doświadczeń konstruowania zadań z języka obcego dla tej grupy uczniów dał o sobie wyraźnie znać. Decyzja w sprawie zakresu wymagań w istocie oddana jest osobom zaangażowanym w przygotowywanie zadań egzaminacyjnych, co odczytywać można jako marginalizowanie pewnych podmiotów edukacji, przy zachowaniu oficjalnych pozorów równości. Żadne dane ministerialne nie ujawniają wyników uczniów w różnych formach organizacyjnych (szkoła specjalna, szkoła integracyjna, szkoła ogólnodostępna).

Najogólniej można powiedzieć, że w kontekście kształcenia specjalnego polskim systemem edukacji rządziła zasada nadrabiania zaległości. Dokonywano zmian „zadekretowanych” odgórnie, które wyrosły z krytyki i interpretacji rzeczywistości edukacyjnej. Dążono do zmiany realności edukacji, nie uwzględniając zmiany świadomości jej podmiotów. W następstwie tak wprowadzanych zmian w polskich szkołach dość dobrze zaczęła się zadomawiać strategia pozornej realizacji reform, powierzchownej adaptacji kategorii importowanych z zagranicznych systemów edukacji lub też innych dziedzin życia społecznego. Bez zmiany świadomości nowe struktury wypełniały się starą treścią. 


\section{Kultura szkoły, struktury i praktyki - codzienność szkolna szkół ogólnodostępnych i integracyjnych do poprawy?}

Analiza danych w odwołaniu do systemowego podziału na szkolnictwo ogólnodostępne, integracyjne i specjalne wskazuje, że zjawisko zmiany szkoły przez uczniów z niepełnosprawnością $\mathrm{w}$ toku edukacji wzrasta $\mathrm{z}$ każdym etapem edukacji i w najmniejszym stopniu dotyczy szkół specjalnych (por. P. Grzelak, P. Kubicki, M. Orłowska, 2014; B. Grzyb, 2013; A. Sadownik, 2011). W świetle raportu IBE, z badań prowadzonych w latach 2013-2014 w losowo wybranych z całej Polski szkołach, na etapie szkoły podstawowej, 3/4 uczniów z niepełnosprawnością zmieniających szkołę pierwszego wyboru to uczniowie szkoły ogólnodostępnej (72,3\%), niższy odsetek przypada szkołom integracyjnym $(16,7 \%)$, a najniższy szkołom specjalnym (11\%). W grupie uczniów z niepełnosprawnością, zmieniających szkołę pierwszego wyboru na etapie gimnazjum, wskaźniki dla poszczególnych szkół kształtują się odpowiednio: szkoły ogólnodostępne - $69,1 \%$, szkoły integracyjne $-16,2 \%$; szkoły specjalne $-14,7 \%$. $\mathrm{Z}$ informacji rodziców wynika, że powodem specyficznym dla odejść ze szkół specjalnych jest zmiana miejsca zamieszkania, zaś przypadki odejść ze szkół ogólnodostępnych i integracyjnych wiążą się w zdecydowanej większości z nieradzeniem sobie przez dziecko w szkole (P. Grzelak, P. Kubicki, M. Orłowska, 2014, s. 46-47 i s. 65).

W świetle badań Alicji Sadownik (2011) przejście uczniów z niepełnosprawnością intelektualną ze szkoły masowej do szkoły specjalnej to niezwykle kojący/wyzwalający moment dla badanych. Opisują oni społeczną przestrzeń szkoły specjalnej jako sprzyjającą zrozumieniu ich stylu i tempa uczenia się. Opowiadają o ciekawych dla siebie zajęciach, zaangażowaniu w istniejące w szkole kółka i konkursy. Mimo że przejście do szkoły specjalnej interpretowane jest przez większość uczniów (grupę zdiagnozowanych na poziomie gimnazjalnym lub zawodowym) w kategoriach działania niesłusznego i/lub niesprawiedliwego, to uczniowskie konceptualizacje codzienności w szkole specjalnej odsyłają do kategorii spokoju, zrozumienia, „fajności” i przyjemności. Znaczenia przypisywane szkolnym doświadczeniom A. Sadownik wyprowadziła z analizy 67 wywiadów narracyjnych z uczniami szkoły zawodowej specjalnej. Interpretacja narracji ujawnia, że wspólny wszystkim uczniom w szkole masowej jest brak sukcesu szkolnego, objawiający się złymi ocenami, co prowadziło ostatecznie do szkoły specjalnej. Analizy narracji 22 uczniów specjalnej szkoły zawodowej (wszyscy mieli wcześniejsze doświadczenie w szkole ogólnodostępnej), przeprowadzone przez K. Materny (2012), także potwierdzają negatywne do- 
świadczenia uczniów w szkołach ogólnodostępnych. Symptomatyczna jest wypowiedź jednego z badanych, odnosząca się wprost do pracy nauczycieli: „We wcześniejszej szkole [...] nauczyciele czasami bili dziennikami po głowie, co było takie już niesprawiedliwe. [...] Nigdy nie pomagali, nawet nie chcieli. Znielubiłem tej szkoły. Przestałem chodzić. Dałem se takiego luzu i przestałem chodzić do szkoły" (K. Materny, 2012, s. 120). Podobny obraz doświadczeń wyłania się z wywiadów z uczniami gimnazjum specjalnego, jakie przeprowadziła Katarzyna Gabryś (2005). Uczniowie (wszyscy badani mieli większe lub mniejsze doświadczenia w szkole ogólnodostępnej) szkołę ogólnodostępną wspominają najczęściej jako przykrą, miejsce nieustannych niepowodzeń. Tylko w nielicznych wypowiedziach pojawiała się nutka żalu, że nie można było kontynuować edukacji w szkole ogólnodostępnej. Powtórzyć należy, że dla uczniów zmieniających szkołę szkoła specjalna jest ważnym miejscem budowania/odbudowywania poczucia kompetencji, poczucia własnej wartości, dobrych relacji społecznych. Przyjazny obraz szkoły, satysfakcja ze szkoły wiąże się niewątpliwie z dobrymi kontaktami z nauczycielami, u których uczniowie znajdują zrozumienie i wsparcie, z satysfakcjonującymi stosunkami z rówieśnikami, ale także z możliwościami realizacji własnej osoby (por. S. Sadowska, Z. Janiszewska-Nieścioruk, 2015a).

Jak środowisko szkoły integracyjnej oceniają uczniowie z niepełnosprawnością intelektualną? Istotnych przesłanek dostarczają badania zadowolenia ze szkoły uczniów z niepełnosprawnością intelektualną w stopniu lekkim, uczących się w szkołach specjalnych i integracyjnych (S. Sadowska, 2006b, s. 203268). Ujawniają one, że w wielu sferach życia w szkole zadowolenie uczniów szkół integracyjnych jest niższe od zadowolenia uczniów ze szkół specjalnych. Niższa ogólna satysfakcja uczniów szkół integracyjnych z lekcji wynika przede wszystkim z niższego - w stosunku do uczniów szkół specjalnych - zadowolenia z trudności zadań na lekcji i trudności zadań domowych oraz z niższego zadowolenia z tempa pracy na lekcjach (dawanego czasu na wykonanie zadania). Wyniki badań dowodzą, że uczniowie szkół integracyjnych i szkół specjalnych są zadowoleni ze stosunków z nauczycielami. Różnice między uczniami tych szkół ujawniły się na etapie gimnazjum. Kategoriami różnicującymi okazały się zadowolenie z zaufania do nauczycieli i zadowolenie z partnerskiego traktowania przez nauczycieli. Wyniki badań wskazały, że uczniowie szkół integracyjnych są istotnie mniej zadowoleni z omawianych dwóch kategorii. Najbardziej różnicującym obszarem grupę uczniów ze szkół integracyjnych i specjalnych jest zadowolenie ze stosunków z kolegami. Hierarchia wartościowania wskazuje, że kontakty z rówieśnikami przynoszą uczniom szkół integracyjnych mniej 
satysfakcji niż uczniom ze szkół specjalnych. Obszarem najbardziej satysfakcjonującym uczniów szkół integracyjnych jest sfera infrastrukturalno-organizacyjna. Wyniki zdają się sugerować, że poczucie przynależności do szkoły jest w większym stopniu poczuciem przynależności do miejsca (przestrzeń fizyczna) niż do społeczności (zwłaszcza rówieśniczej). W zakresie wymiaru „opieka" istotne różnice między badanymi grupami dotyczyły zadowolenia z dbałości szkoły o wyżywienie. Kategoria ta okazała się niezwykle istotna (przynosząca dużo satysfakcji) dla uczniów szkół specjalnych. Uczniowie szkół integracyjnych są mniej usatysfakcjonowani z tego wymiaru, co może wskazywać na niespełnienie ich oczekiwań w tym zakresie. W wymiarze ,zajęcia pozalekcyjne" kategoriami przynoszącymi najwięcej satysfakcji uczniom szkół specjalnych i najmniej satysfakcji uczniom szkół integracyjnych są oferta (wielość, atrakcyjność) kół zainteresowań oraz oferta (atrakcyjność, rozmaitość) zajęć sportowych. Zauważę, że wyniki wyższej satysfakcji uczniów szkół specjalnych z wielu sfer życia nie przekładają się na ogólne zadowolenie ze szkoły. Uczniowie ze szkół integracyjnych wyrażali istotnie wyższą satysfakcję ze szkoły w porównaniu do uczniów szkół specjalnych. Z pewnością jest to związane ze społeczną oceną szkoły integracyjnej, której zarówno bliższe, jak i dalsze otoczenie przypisuje wyższe znaczenie.

Wyjaśnienie uczniowskich ocen dotyczących szkoły, czy rozpoznanie mechanizmów prowadzących do zmiany szkoły, jest możliwe, gdy rozpoznamy nie tyle oficjalne deklaracje, co konkretne zachowania, sposoby myślenia nauczycieli i uczniów. Antropolog Roch Sulima podkreślał, że o codzienności dużo mówią rzeczy w działaniu, a nie rzeczy w katalogach, spisach i taksonomiach (M. Dudzikowa, M. Czerepaniak-Walczak, 2010, s. 15). Jego słowa wskazują, że odsłanianie ukrytych, a nie jawnych wzorów kultury szkoły więcej powie o codzienności. Kultura jawna to rytuały, przekonania, wartości, a w końcu wzorce zachowań i sposoby myślenia ludzi, które są „oficjalne”, deklarowane. To o nich zazwyczaj traktują wewnątrzszkolne dokumenty zawierające misję i wizję szkoły, plakaty rekrutacyjne czy strony internetowe. Kultura ukryta zaś to te same elementy, ale nienazywane wprost, nieakceptowane i niepromowaneczęsto sprzeczne z wartościami deklarowanymi oficjalnie. To wartości i przekonania, które manifestują się nie w słowach, lecz w zachowaniach (por. D. Szczecińska, 2010).

Przyglądając się codzienności szkolnej, dostrzec można rozbieżność między oficjalnymi deklaracjami a sposobami myślenia i zachowaniami ludzi. Rozwiązania w procesie dydaktycznym nie zasadzają się na kooperacji uczniów, co więcej - to często segregacyjne praktyki, dotyczy to także klas, które noszą 
miano integracyjnych. Jedna z badanych przez Katarzynę Błuszkowską (2012, s. 115) wspomina pracę w klasie integracyjnej następująco: „to były dwie oddzielne klasy, równie dobrze mogłaby być między tymi częściami klasy postawiona ściana i po prostu tam by były jedne zajęcia dla jednych, tu by były drugie z innym nauczycielem dla drugich". Badani uczniowie z klas integracyjnych podkreślają wyraźne rozdzielenie działań uczniów pełnosprawnych i niepełnosprawnych, co wiąże się z rozdzieleniem ról nauczycieli. Głębsze interpretacje pozwalają zauważyć, że działania dydaktyczne w klasach integracyjnych i ogólnodostępnych bazują z jednej strony na specyficznym dla polskiej szkoły wzorze wiedzy, dziecka i dzieciństwa, z drugiej - na wzorze dziecka niepełnosprawnego i osoby niepełnosprawnej.

Można powiedzieć, że zapleczem myślowym dla praktyk wspólnego kształcenia jest „teoria dwóch grup” - osób pełnosprawnych i osób niepełnosprawnych. W sposób szczególny ujawnia to praktyka edukacji w klasach integracyjnych. Opiera się ona na założeniu, że dzieci niepełnosprawne wymagają specjalnego podejścia, a ich kształcenie ma tak silną specyfikę, iż może być prowadzone tylko przez osoby o specjalistycznym wykształceniu. Powstają dwa równoległe systemy świadczenia usług edukacyjnych, działające w jednej architektonicznej przestrzeni - dla uczniów pełnosprawnych i niepełnosprawnych (por. G. Szumski, 2004, s. 44). Takie rozwiązanie bliskie jest modelowi integracji, który krytykowany jest z perspektywy nowego podejścia - inkluzyjnego. Wzór pracy biegnący dwoma torami kształcenia wzmacniany jest wzorem przekazu wiedzy i zapisami głównego aktu prawnego stanowiącego fundament programów edukacyjnych - podstawy programowej. Dorota Klus-Stańska podkreśla, że „głęboko zinternalizowanym wzorem, stanowiącym punkt wyjścia myślenia o procesie edukacyjnym w polskiej szkole, jest definicja wiedzy [...]. Zgodnie z nią wiedza to wyznaczony przez program nauczania zbiór wiadomości przekazywanych przez nauczyciela w celu jej przyswojenia. U podstaw takiej „odruchowej” kulturowej identyfikacji leży cała sieć wzorów $[\ldots]-[\ldots]$ wzory dziecka i dzieciństwa, wytworzone przez wybór odpowiedzi na takie pytania, jak: Kim jest dziecko? Jakie ma możliwości? Na ile można mu zaufać? Jaką wartość ma jego rozumienie świata? Czemu służy przeżywanie dzieciństwa? Oraz jeszcze szersze zakresowo: W jaki sposób rozwija się człowiek? Skąd pochodzi wiedza w umyśle? Jak człowiek uczy się być z innymi? Jakie skutki tożsamościowe ma władza nad myśleniem?" (D. Klus-Stańska, 2010, s. 322). Głęboka internalizacja wzoru wiedzy i jej przekazu wzmacniana jest zapisami podstawy programowej, która napisana jest z perspektywy indywidualizmu. „Widać wyraźne przywiązanie do pedagogiki indywidualnych efektów, 
z którymi uczeń musi poradzić sobie sam, gdyż indywidualnie poddany zostanie testom psychotechnicznym, egzaminom i pomiarom efektów. [...] Stereotypowe rozumienie wiadomości i umiejętności jako zdolności odtwarzania lub deklarowania posiadanych informacji (bo nie wiedzy) wyraża się w użytych czasownikach $<<$ wie $>>$, $<<$ zna $>>$, $<<$ odtwarza z pamięci $>>$, $<<$ nazywa $>>$ " (I. Kopaczyńska, 2013, s. 225).

Analiza form i semantyki wypowiedzi nauczycieli świadczy o stereotypowym ujmowaniu osób z niepełnosprawnością. W słowniku nauczycieli osoba niepełnosprawna jest „bezradna”, „zależna od innych osób”, a nawet „,zdana całkowicie na pomoc osób trzecich". W semantycznych strukturach pokazujących swoiste dla nauczycieli widzenie osób niepełnosprawnych odbija się ogólniejsze rozumienie organizacji świata, panujących w nim hierarchii i akceptowanych przez tę społeczność językową wartości. Sytuacja osób niepełnosprawnych opisywana jest także poprzez konstrukcje, których centrum znaczeniowe i pojęciowe tworzą słowa podkreślające ograniczenia i problemy. Najczęściej wyraża to zaprzeczenie czasownika: „nie funkcjonuje”, „nie poradzi sobie”, „nie może ..”. itp. Inne językowe kategorie wyrażające to samo znaczenie to: imiesłów „ograniczona” oraz rzeczowniki „ograniczenia”, „trudności”, „niemożność”. Programy działania wpisane w wypowiedzi nauczycieli dotyczą opieki, pomocy, wsparcia, szczególnej troski, bardzo rzadko współpracy zdrowych czy traktowania jak każdego innego (por. S. Sadowska, 2005, s. 102-120). Wzór pomagania przenika praktyki edukacyjne w szkołach, w których uczą się uczniowie z ograniczoną sprawnością. Wpisany jest on nie tylko w działania nauczycieli, lecz również w oczekiwania, jakie nauczyciele stawiają uczniom pełnosprawnym (por. S. Sadowska, 2015).

Wzory działań wychowawczych mają niewiele wspólnego z budowaniem świadomości MY. Dobre wychowanie wiązane jest z programem wychowawczym szkół, który nie tyle mówi nauczycielowi, jakie wartości uczeń powinien cenić, czy, jakie kompetencje społeczne powinien ujawniać, ile i kiedy ma zaangażować się w formy działań ustalonych w szkole, traktowane jako realizacja tego programu. Nauczyciele wskazują, że zadaniem szkoły jest kształtowanie postawy tolerancji, przypisują w tym zakresie odpowiedzialność przede wszystkim wychowawcom klas, gdyż jest to wpisane w program wychowawczy, wyrażają często zdanie, że sam fakt istnienia w szkole klas integracyjnych wpływa na kształtowanie postaw tolerancji wśród uczniów, na ich „oswajanie” się z niepełnosprawnością, wskazują też, że włączanie treści o osobach niepełnosprawnych w proces edukacyjny to obowiązek twórców podstawy programowej, autorów podręczników. Odpowiedzialność innych jest charakterystycznym rysem 
myślenia i działania nauczyciela. Osobiste działanie nauczyciele sprowadzają do ewentualnych pogadanek ,uwrażliwiających” uczniów na osoby niepełnosprawne, które nakierowane są na normę społeczną ,pomocy” (por. M. Gołubiew-Konieczna, 2002; S. Sadowska, 2005; K. Magrian, 2012). Nauczyciele, racjonalizując opcjonalność własnego działania, odwołują się do schematu znaczeń nadawanych przez nich pracy i znaczeń nadawanych doświadczeniu szkolnemu przez uczniów. Piotr Stańczyk (2012) wskazuje, że sens pracy nauczycieli sprowadza się w ich ujęciu do doprowadzenia przedmiotu ich pracy ucznia - do zaadaptowania się poprzez zajęcie miejsca w strukturze społecznej. W te sensy wpisują się znaczenia nadawane byciu w szkole przez uczniów. Dla schematu tych doświadczeń centralną kategorią jest „bycie ocenianym”, które łączy się ze „,zdobywaniem wiedzy”. Nauczyciele argumentują: „,nauczyciel [jest - przyp. S.S.] rozliczany z testów, wyników i nie skupia się, żeby zrobić pogadankę, tylko z reguły na godzinach wychowawczych realizuje się polski czy matematykę" (K. Magrian, 2012, s. 76). Zauważę, że przekonanie nauczycieli, że włączanie treści o osobach niepełnosprawnych w proces edukacyjny to obowiązek twórców podstawy programowej i autorów podręczników jest niebezpieczne, gdyż potencjał socjalizacyjny podręcznika, na który składają się rekomendowane systemy wartości, wzorce ról społecznych, postaw i interpersonalnych relacji, zakres podejmowanej tematyki oraz sposób jej konceptualizacji trzeba ocenić krytycznie (por. S. Sadowska, 2005, s. 145-181). Teksty szkolne o osobach z niepełnosprawnością oraz zaproponowane w podręcznikach pytania i polecenia do tekstów kierują uwagę ucznia na odbiegającą od normy sprawność oraz uczucia smutku, lęku przed kontaktem z dzieckiem pełnosprawnym i radości jako efektu kontaktu. Prezentacja osób niepełnosprawnych każe interpretować ich sytuację w kategoriach „gorszy”/,wymagający pomocy". Logika socjalizacji i logika edukacji w zakresie kształtowania kompetencji do współdziałania z ludźmi niepełnosprawnymi więc się od siebie nie różni.

Wzory działań dydaktycznych i wychowawczych w polskich szkołach mają niewiele wspólnego z modelem inkluzji, którego podstawą jest kultura włączająca. To na jej bazie budowane są struktury włączające, czyli taki sposób organizacji szkoły, w którym wszystkie podejmowane działania podporządkowane są idei szkoły dla wszystkich (istotną rolę odgrywają tu sposoby tworzenia grup uczniowskich). Jest ona też podstawą dla włączających praktyk - metod nauczania i wychowania dostosowanych do różnorodności uczniów (por. G. Szumski, 2004; 2010). Praktyki i sposoby myślenia w szkołach ogólnodostępnych i integracyjnych wskazują na wiele barier (środowiskowych, dotyczących strategii nauczania i uczenia się, postaw, zachowań oraz organizacji 
i zarządzania), które uniemożliwiają pełne uczestnictwo dzieci z niepełnosprawnością intelektualną w procesie edukacyjnym. Nie prowadzą też do niwelowania negatywnych postaw uczniów wobec osób niepełnosprawnych, nie budują podstaw, by edukacja była wartościowa dla zmiany społecznej.

\section{Co dalej?}

Krytyczne rozpoznanie przejawów wzorów określających i organizujących szkolną codzienność jest znaczące, by zmienić status quo. Zbyszko Melosik, odnosząc się do teorii i praktyki edukacyjnej w kontekście kultury współczesnej, stwierdza: „Szukamy <<edukacji adekwatnej>>, zarówno w kontekście teorii, jak i praktyki, takiej, która wywiera realny wpływ na młode pokolenie i która może stanowić źródło zmiany społecznej. <<Adekwatność>> nie oznacza w tym kontekście nic innego, jak <<wrażliwość>> na otaczającą nas rzeczywistość i jej przemiany oraz otwarcie na nowe propozycje w zakresie poznawania, wyjaśniania i opisywania świata, jak również na nowe idee. To z kolei wiąże się ze stałą gotowością do rezygnacji z dotychczasowych nawyków myślenia, do kwestionowania własnych $<<$ konceptualnych schematów $>>$ " (Z. Melosik, 2003, s. 19).

Zniewoleniem krytycznie nierozpoznanym jest władza, jaką nad nami sprawuje kulturowa oczywistość - mówi R. Kwaśnica (2014). Wskazuje, że rozum instrumentalny zawłaszczył sobie przestrzeń edukacji, podobnie jak przestrzeń społeczną. Cele, plany, strategie, pomiar efektów, środki, różne zasoby ludzkie stanowią charakterystyczny „,słownik” myślenia i mówienia o edukacji. Żeby myśleć o szkole, trzeba opisywać ją i projektować jej działanie za pomocą takich samych pojęć i kategorii, którymi myślimy o zasadach wszystkich instytucji (instrumentalna funkcjonalność, techniczna i biurokratyczna sprawność, organizacja). Kulturowa oczywistość wymusza instrumentalne myślenie o procesach dziejących się w obszarze edukacji (nauczanie, uczenie się, wychowanie, kształcenie) oraz ich uczestnikach (nauczyciele, uczniowie, rodzice). Działanie musi być skuteczne i zgodne z racjonalnością celów. Podzielamy myślenie, że nieprzemijającym obowiązkiem szkoły, uzasadnionym racjonalnie jest przekazywanie wiedzy naukowo-technicznej. Każdy inny projekt celów szkoły jest nieracjonalny i niezasługujący na uznanie. $Z$ celami postulowanymi racjonalność działania szkoły ma związek dość odległy, pośredni, wybiórczy. Przedkrytycznie uznajemy cele szkoły nie za to, czym rzeczywiście są, czyli - za projekt powinności szkoły, lecz za to, czym nie są, czyli - za opis rzeczywistych jej zadań (R. Kwaśnica, 2015, s. 156-157). By przełamać władzę, jaką 
nad nami sprawuje kulturowa oczywistość, R. Kwaśnica opowiada się za refleksją hermeneutyczną. Wskazuje, że ,pozostające w kole hermeneutycznym jej rozumienie odmienia stale naszą zależność od niej, a przez to - nas samych i świat, w którym żyjemy" (R. Kwaśnica, 2014, s. 233).

D. Klus-Stańska, analizując praktyki dydaktyczne w szkole, wypowiada się bardzo podobnie. Podkreśla, że nauczyciele traktują wzory działania w szkole jako niedyskursywną „oczywistą oczywistość”. Podkreśla, że bezrefleksyjne zanurzenie we własnej kulturze i nieświadomość jej „nienaturalności” blokują możliwość jej poznania (D. Klus-Stańska, 2010, s. 325). Krytyczne rozpoznanie mogą uruchamiać środowiska naukowe poprzez odsłanianie istoty i następstw dziejących się codziennych spraw szkolnych, opis i interpretację wykonań składających się na znaczący strumień codziennych szkolnych wydarzeń, a więc taki, który znaczy uczniowski „dzień jak co dzień”.

W działaniu edukacyjnym, w którym kontrolowane są wartości, cele, treści edukacji, podstawowa jest refleksja nad tym, o jaki obraz człowieczeństwa nam chodzi. Jest to klucz do kształtowania kultury szkoły. Narzędziem kształtowania kultury szkoły są wspólnie wypracowane i podzielane przez nauczycieli wartości. Przy czym nie chodzi tu tylko o ogólną wizję i misję, ale o bardzo konkretne wyobrażenie tego, co każdy pracownik może zrobić, aby szkoła była taka, jaką być powinna. Opowiedzieć się za taką drogą można tylko w jeden sposób - wspierając innych w hermeneutycznej refleksyjności i samemu próbując ją uprawiać. Od tego już niedaleka droga do rozwiązania, w którym upatruje się nie tylko wpływu na młode pokolenie, ale i takiego wpływu, który jest źródłem zmiany społecznej. W tak szerokim rozumieniu należy rozumieć realizację projektu inkluzji. Inkluzja to bowiem wizja edukacji (nie tylko uczniów z niepełnosprawnością), która jest transcendentna wobec zastanej rzeczywistości. W jej kontekście niepokoi zawężanie edukacji tylko do patrzenia na nią jako na usługę o charakterze komercyjnym, mającą sprostać wymaganiom rynku pracy. Cele procesu uczenia się nie mogą ograniczać się tylko do nabycia utylitarnej wiedzy i umiejętności związanych z odniesieniem sukcesu w zawodzie. Takie rozumienie roli edukacji powoduje jej odhumanizowanie, oderwanie od systemu wartości, pragnień i potrzeb duchowych człowieka.

Humanizowanie człowieka to budowanie jego wrażliwości dyskursywnej i uczenie refleksji hermeneutycznej. Ważny jest sens stawianych zadań, relacje między uczniem a nauczycielem, tworzenie konfliktów poznawczych i aksjologicznych w miejsce ich pozorowania. Wartość wiedzy nie może tkwić w jej pewności, lecz w refleksyjności, a nawet $\mathrm{w}$ wywoływaniu niepewności. W program edukacji muszą być wpisane różnice i sprzeczności informacyjne, jako 
podstawa konfrontacji poznawczej. Idzie też o odczucie przez ucznia problematyczności społecznie konstruowanego świata, odczucie oparte na przekonaniu, że świat kultury jest światem konstruowanym i dlatego poddającym się rekonstrukcyjnym działaniom podmiotu (A. Męczkowska, 2002; S. Sadowska, 2005). Urzeczywistnianie projektu inkluzji bliskie jest zadaniu hermeneutycznej humanistyki. W odwołaniu do słów M.P. Markowskiego jej zadaniem jest „przekształcenie społecznego imaginarium, a więc wpływ na to, jak i co ludzie myślą o świecie, tu i teraz, dziś i za chwilę. [...] Humanistyka pokazuje, że nie istnieje jeden słownik, którym możemy świat objaśnić, nie istnieje jedna nadrzędna ideologia, którą możemy się posługiwać [...]. Humanistyka uwrażliwia nas to na to, że żaden z obiegowych słowników nie jest ostateczny i zawsze można go zmienić na inny, lepiej nam służący, lepiej odpowiadający nie rzeczywistości, lecz naszym przeświadczeniom, naszym przekonaniom, naszym marzeniom" (za: R. Kwaśnica, 2014, s. 248). Nie wystarczy znajomość specjalnych metod, środków pracy z uczniami z niepełnosprawnością, gdy nie zrozumiemy sensu edukacji, sensu naszych działań, w tym ukrytych znaczeń wydarzeń w codzienności szkolnej. W takim kontekście należy odczytywać ujęcie UNESCO, że „edukacja włączająca, jest nieustannie trwającym procesem ukierunkowanym na oferowanie wysokiej jakości edukacji dla wszystkich oraz poszanowanie różnorodności, różnych potrzeb i zdolności, właściwości i oczekiwań uczniów i społeczności eliminującym wszelkie formy dyskryminacji” (za: B. Papuda-Dolińska, 2012, s. 427).

\section{Bibliografia:}

Błuszkowska K. (2012), Doświadczenia edukacyjne petnosprawnych absolwentów klas integracyjnych - niepublikowana praca magisterska napisana pod kierunkiem dr hab. Sławomiry Sadowskiej, Gdańsk.

Buksiński T., Podstawy aksjologiczne sfery publicznej, „Filo - Sofija”, nr 1.

Chrzanowska I. (2002), Uczeń z upośledzeniem umysłowym w szkole ogólnodostępnej, w: W. Dykcik, C. Kosakowski, J. Kuczyńska-Kwapisz (red.), Pedagogika specjalna szansą na realizacje potrzeb osób z odchyleniami od normy, Wyd. Naukowe PTP, Olsztyn-Poznań-Warszawa.

Chrzanowska I. (2013), Strategia kształcenia osób niepetnosprawnych. Diagnoza pozoru, w: Z. Gajdzica (red.), Człowiek z niepetnosprawnościa w rezerwacie przestrzeni publicznej, OW „Impuls”, Kraków. 
Dudzikowa M., Czerepaniak-Walczak M. (2010), Codzienność w szkole, szkoła w codzienności, w: M. Dudzikowa, M. Czerepaniak-Walczak (red.), Wychowanie. Pojęcia-Procesy-Konteksty, t. 5, Gdańsk.

Eckert U. (1999), Powiazania pedagogiki specjalnej z pedagogika ogólna jako element jakości edukacji, w: J. Pańczyk, W. Dykcik (red.), Pedagogika specjalna wobec zagrożeń $i$ wyzwań XXI wieku. Materiały z obrad XVI sekcji III Zjazdu Pedagogicznego w Poznaniu (21-23 wrzesień 1998), Wyd. UAM, Poznań.

Gabryś K. (2005), Kategorie personalistyczne w myśleniu o osobach niepetnosprawnych intelektualnie, w: Klinik A., Rottermund J., Gajdzica Z. (red.), Edukacja-socjalizacja - autonomia w życiu osoby niepetnosprawnej, OW „Impuls”, Kraków.

Gołubiew-Konieczna M. (2002), Program wychowawczy szkoły narzędziem wspierania integracji w placówce oświatowej, w: W. Dykcik, C. Kosakowski, J. Kuczyńska-Kwapisz (red.), Pedagogika specjalna szansą na realizację potrzeb osób z odchyleniami od normy, Olsztyn-Poznań-Warszawa.

Grzelak P., Kubicki P., Orłowska M. (2014), Realizacja badania ścieżek edukacyjnych niepetnosprawnych dzieci, uczniów i absolwentów - raport końcowy, Wyd. Instytut Badań Edukacyjnych, Warszawa.

Grzyb B. (2013), Uwarunkowania związane z przenoszeniem uczniów niepetnosprawnych ze szkót integracyjnych do specjalnych, OW „Impuls”, Kraków.

Klus-Stańska D. (2010), Dzień jak co dzień. O barierach zmiany kultury szkoły, w: M. Dudzikowa, M. Czerepaniak-Walczak (red.), Wychowanie. Pojęcia-Procesy-Konteksty, t. 5, Gdańskie Wydawnictwo Psychologiczne, Gdańsk.

Kłakówna Z.A. (2014), Jakoś i jakość. Subiektywna kronika wypadków przy reformowaniu szkoty (1989-2013), UNIVERSITAS, Kraków.

Kopaczyńska I. (2013), Podstawa programowa dla klas I-III szkoty podstawowej jako punkt wyjścia działań pozornych, w: M. Dudzikowa, K. Knasiecka-Falbierska (red.), Sprawcy i/lub ofiary działań pozornych w edukacji szkolnej, Kraków.

Kowalik S. (2001), Pomiędzy dyskryminacją a integracja osób niepetnosprawnych, w: B. Kaja (red.), Wspomaganie rozwoju. Psychostymulacja - psychokorekcja, Wyd. Uczelniane Akademii Bydgoskiej, Bydgoszcz.

Krause A. (2004), Człowiek niepetnosprawny wobec przeobrażeń społecznych, Wyd. „Impuls", Kraków.

Kwaśnica R. (2014), Dyskurs edukacyjny po inwazji rozumu instrumentalnego. O potrzebie refleksyjności, Wyd. DSW, Wrocław.

Magrian K. (2012), Nauczycielskie koncepcje edukacji o niepetnosprawności w szkole ogól- 
nodostępnej z oddziałami integracyjnymi - niepublikowana praca magisterska napisana pod kierunkiem dr hab. Stawomiry Sadowskiej, Gdańsk.

Materny K. (2012), Biografia miejsca - obraz szkoły specjalnej w narracjach uczniów, w: Krause A., Belzyt J., Sadowska S. (red.), Dyskursy Pedagogiki Specjalnej, nr 10. Szkoła dla osób z niepetnosprawnością. Wzory - Codzienność - Wyzwania, Wydawnictwo Uniwersytetu Gdańskiego.

McLaren P. (1994), Pedagogika Freirego wobec postmodernizmu i kondycji Akademii, w: J. Brzeziński, L. Witkowski (red.), Edukacja wobec zmiany społecznej, Wyd. Edytor, Poznań-Toruń.

Melosik Z. (2003), Edukacja, młodzież i kultura wspótczesna. Kilka uwag o teorii i praktyce pedagogicznej, „Chowanna” tom 1 .

Męczkowska A. (2002), Od świadomości nauczyciela do konstrukcji świata społecznego. Nauczycielskie koncepcje wymagań dydaktycznych a problem rekonstrukcyjnej kompetencji ucznia, OW „Impuls”, Kraków.

Mittler P. (2000), Czyje potrzeby? Czyje interesy?, w: G. Fairbairn, S. Fairbairn (red.), Integracja dzieci o specjalnych potrzebach. Wybrane zagadnienia etyczne, Wyd. Centrum Metodyczne Pomocy Psychologiczno-Pedagogicznej MEN, Warszawa.

Papuda-Dolińska B. (2012), Realizacja koncepcji inkluzji edukacyjnej w szkołach Planu Jenajskiego - doświadczenia holenderskie, w: N. Starik, A. Zduniak (red.), Podmiotowość w edukacji wobec odmienności kulturowych oraz społecznych zróżnicowań, Poznań, s. 427-439.

Puchalski Z. (2014), Kształcić odważnych obywateli, w: A. Rękawek, J. Kostynowicz (red.), 25 LAT warszawskiej edukacji w wolnej Polsce. Skąd przychodzimy, gdzie jesteśmy, dokad idziemy? Rozmowy. Inspiracje, Warszawskie Centrum Innowacji Edukacyjno-Społecznych i Szkoleń 30 maja 2014; http://edukacja.warszawa.pl/sites/edukacja/files/ informacje-dla-nauczycieli-i-dyrektorow/6034/attachments/25_lat_warszawskiej_edukacji_4_06_2014.pdf, dostęp: 18.02.2016.

Rawls J. (1994), Teoria sprawiedliwości, przekład: Maciej Panufnik, Jarosław Pasek, Adam Romaniuk, PWN, Warszawa.

Sadownik A. (2011), Na rozstajnych drogach. Studium etnopedagogiczne kontrastowych karier szkolnych młodzieży, Wyd. Naukowe Dolnośląskiej Szkoły Wyższej, Wrocław.

Sadowska S. (2005), Ku edukacji zorientowanej na zmianę społecznego obrazu osób niepetnosprawnych, Wyd. Edukacyjne „AKAPIT”, Torun.

Sadowska S. (2006a), Drogi (i bezdroża) nauczania matematyki uczniów z niepetnospraw- 
nościa intelektualna w stopniu lekkim, w: S. Sadowska (red.), Nauczanie uczniów z niepetnosprawnościq intelektualna $w$ stopniu lekkim. Wybrane problemy teorii i praktyki, Wyd. Edukacyjne „Akapit”, Toruń, s. 165-188.

Sadowska S. (2006b), Jakość życia uczniów z niepetnosprawnością intelektualna w stopniu lekkim, OW „Impuls”, Kraków.

Sadowska S. (2013), Egzamin gimnazjalny 2012 dla uczniów ze specjalnymi potrzebami edukacyjnymi - o jawnych i ukrytych sposobach myślenia osób zaangażowanych we wdrażanie zmian, „Szkoła Specjalna”, s. 325-343.

Sadowska S. (2015), Praktyka tworzenia edukacyjnej wspólnoty - o edukacyjnej codzienności w kontekście jawnych i ukrytych wzorów kultury szkolnej, „Studia Edukacyjne”, nr 34, s. 71-88.

Sadowska S., Janiszewska-Nieścioruk Z. (2015a), O dobrodziejstwie starej, dobrej szkoły specjalnej $w$ perspektywie realizacji obowiąku szkolnego przez uczniów niepełnosprawnych - napięcia między idea integracji a rzeczywistościa, , Przegląd Badań Edukacyjnych", nr 21, vol. 2, s. 137-152.

Sadowska S., Janiszewska-Nieścioruk Z. (2015b), Sukcesy w dziedzinie zewnętrznego sprawdzania efektów ksztatcenia uczniów z niepetnosprawnościami? Refleksje w odniesieniu do sprawdzianu po szkole podstawowej, „Niepełnosprawność. Dyskursy pedagogiki specjalnej", nr 20, s. 86-110.

Sandel M. J. (2013), Sprawiedliwość. Jak postępować słusznie?, przekład: O. Siara, Wyd. Kurhaus, Warszawa.

Stańczyk P. (2012), Praca, w: M. Cackowska, L. Kopciewicz, M. Patalon, P. Stańczyk, K. Starego, T. Szkudlarek (red.), Dyskursywna konstrukcja podmiotu. Przyczynek do rekonstrukcji pedagogiki kultury, Wyd. UG, Gdańsk.

Szczecińska D. (2010), Kultura organizacyjna efektywnej szkoty, w: I. Nowosad, I. Mortag, J. Ondráková (red.), Jakość życia i jakość szkoty. Wprowadzenie w zagadnienia jakości i efektywności pracy szkoły, Oficyna Wydawnicza Uniwersytetu Zielonogórskiego, Zielona Góra.

Szumski G. (2004), Od kształcenia integracyjnego do edukacji inkluzyjnej - przemiany idei i praktyki-przemiany idei i praktyki, w: C. Kosakowski, A. Krause (red.), Dyskursy pedagogiki specjalnej. Rehabilitacja, opieka i edukacja specjalna w perspektywie zmiany, Wyd. UWM, Olsztyn.

Szumski G. (2010), Wokót edukacji włączającej. Efekty kształcenia uczniów z niepetnosprawnościa intelektualna $w$ stopniu lekkim $w$ klasach specjalnych, integracyjnych i ogólnodostęnych, Wyd. APS, Warszawa. 
METAANALIZY BADAŃ EDUKACYJNYCH

Śliwerski B. (1998), Lęk wobec nauczycielskiej wolności, w: W. Prokopiuk (red.), Rozwój nauczyciela w okresie transformacji, Wyd. Uniwersyteckie „TRANS HUMANA”, Białystok.

Ustawa z dnia 7 września 1991 r. o systemie oświaty (Dz.U. 1991 Nr 95, poz. 425). 